\title{
OS ESTUDOS SOBRE A HISTÓRIA DA MÚSICA EM SANTA CATARINA Um panorama da produção acadêmica à luz da musicologia
}

MUSIC HISTORY STUDIES IN SANTA CATARINA An overview of academic production according to musicology

Tiago Pereira ${ }^{7}$ 


\section{Resumo}

De caráter bibliográfico, com o intuito de compreender a escrita da história da música em Santa Catarina, realiza-se um mapeamento das pesquisas defendidas sobre esse tema, junto aos programas de Pós-Graduação no Brasil. Os trabalhos são problematizados a partir de enfoques específicos, como a perspectiva institucional, biográfica e voltada à descrição de gêneros e movimentos musicais catarinenses. As pesquisas de cunho científico contribuem para a superação de uma literatura musical parcial e exaltativa. Nota-se uma predominância de trabalhos voltados à capital do estado, dentre pesquisas histórico-musicológicas ou de natureza etnográfica, com um gradativo processo de descentralização. Pode-se dizer, por fim, que todos os trabalhos mapeados trazem importantes contribuições para a escrita e para o entendimento da cultura musical catarinense do passado e do presente.

Palavras-chave: História da música em Santa Catarina; Musicologia histórica catarinense; Pesquisas do estado da arte.

\section{Abstract}

To understand the music history writing about the state of Santa Catarina, a mapping of the academic researches defended on this theme is carried out in Brazilian's graduate programs databases. The works are problematized from specific approaches, such as the institutional, biographical perspective and focused on the description of musical genres and movements in Santa Catarina. Mapped academic researches contributes to overcoming a partial and pretentious musical literature. In historical, musicological or ethnographic research there is a predominance of works focused on music in the state capital, with a gradual process of decentralization. Finally, all the mapped works bring important contributions to the writing and understanding of past and present Santa Catarina's musical culture.

Keywords: History of music in Santa Catarina; Historical Musicology in Santa Catarina; State of the art research.

\footnotetext{
$1 \quad$ Professor da Universidade de Blumenau. Possui mestrado em Música - Musicologia/Etnomusicologia pela Universidade do Estado de Santa Catarina, Udesc e graduação em Música - Licenciatura pela Universidade de Blumenau, Furb. Na pesquisa histórico-musicológica estuda a música nas antigas colônias estrangeiras do Vale do Itajaí catarinense, a partir da sua inter-relação com as matrizes sociocultural e urbana. Atualmente cursa o Doutorado em Música no PPGMUS Udesc na linha de pesquisa Teoria e História.
} 
Por meio deste artigo se busca realizar um mapeamento sistemático dos trabalhos científicos voltados à construção de uma historiografia da música em Santa Catarina, reconhecendo, para essa temática, as contribuições fundamentais oriundas das pesquisas nas várias áreas das ciências humanas. Possibilitar uma compreensão acerca da produção de conhecimento acadêmico voltado às manifestações e atividades musicais catarinenses do passado e do presente é o que marca o propósito desse levantamento bibliográfico, tomando como objetos de estudo, então, as dissertações e teses defendidas junto aos programas de pós-graduação no Brasil até o corrente ano. Nesse sentido, são consideradas as pesquisas entendidas por seus autores como pertencentes à pesquisa em Música - entendida aqui enquanto musicologia, sobretudo a musicologia histórica -, pesquisas produzidas no campo específico da História, bem como trabalhos de natureza híbrida junto à etnomusicologia. Os trabalhos mapeados são descritos procurando delimitar, numa perspectiva geral, que regiões do estado são priorizadas, quais são as principais tendências investigativas, quais são os modelos epistemológicos e estratégias metodológicas dominantes.

Como será possível observar, a produção acadêmica voltada para a escrita de uma história da música no contexto do estado de Santa Catarina é diretamente influenciada pela natureza, pelo debate e pelo desenvolvimento do campo da (nova) musicologia brasileira. Nesse sentido, vale apontar que no Brasil desde o século XIX já havia sido escrita certa quantidade de textos sobre música. Essa produção, de interesse demasiadamente literário, encontrava-se longe de qualquer propriedade científica ou musicológica. ${ }^{2}$ É a partir do século XX que a gênese da literatura brasileira interessada em sua historiografia musical sofre consideráveis modificações. De caráter ensaístico, as chamadas "Histórias da Música no Brasil", ainda que carentes de dados concretos sobre a produção musical brasileira, permutaram de uma fase literário-musical para um gênero intermediário entre literatura e ciência. Influenciadas pelos discursos modernistas do início do último século, essas "histórias" enalteciam compositores brasileiros anteriores e contemporâneos à época, cultivando o passado musical do país e estruturando uma música nacional, ainda que de maneira cientificamente incipiente (CASTAGNA, 2008).

Boa parte da literatura musical do Brasil no século XX estava fundamentada numa leitura bipolarizada do objeto musical. Esta bipolarização manifestava-se nas inúmeras abordagens dualistas entre a música e suas associações com outras áreas de conhecimento, como a literatura, sociologia, história, política e/ou indústria cultural (CONTIER, 1991). Em virtude desta ambiguidade, a música tornou-se objeto de investigação mais de literatos, jornalistas, políticos, sociólogos que propriamente de historiadores - da música, os musicólogos que realizam musicologia histórica. ${ }^{3}$ Este tratamento do objeto musical acabou por gerar literaturas pouco estabelecidas do ponto de vista metodológico e

\footnotetext{
2 A citar os trabalhos de Manuel de Araújo Porto Alegre, Visconde de Taunay, João Barbosa Rodrigues e Sílvio Romero, conforme Castagna (2008). Neste artigo, o autor traça um histórico da musicologia como disciplina no Brasil.

3 Cabe aqui ressaltar que atualmente as abordagens interdisciplinares são de fundamental importância para a musicologia enquanto campo científico - como este próprio trabalho pretende demonstrar no contexto de Santa Catarina -, mas estas abordagens no século XX ainda não estavam concretamente estabelecidas.
} 
principalmente musicológico, acarretando grandes parcialidades e exaltações no levantamento e tratamento das fontes. Esse panorama começou a sofrer alterações sobretudo com os trabalhos de Francisco Curt Lange entre as décadas de 1960 e 1980, contribuindo para que a literatura musical brasileira atingisse um patamar científico, tornando-se musicologia. O musicólogo teuto-uruguaio, interessado principalmente na música praticada em Minas Gerais no período colonial, realizou as primeiras pesquisas arquivísticas com propósitos musicológicos no Brasil, levantando e transcrevendo suntuosas quantidades de documentação de interesse musical. Ainda assim, o trabalho musicológico de Curt Lange estava essencialmente imerso no factual, sendo orientado, conforme ressalta Castagna (2008, p.37), "por uma historiografia positivista, evolucionista e eurocêntrica, com manutenção do interesse biográfico e muito mais ênfase nos compositores do que em sua música", demonstrando na época uma nítida herança dos métodos da musicologia europeia, também apoiada no princípio de ajuntamento de dados.

Sob esta perspectiva, a produção de Curt Lange no Brasil apresentou um caráter expressivamente mais descritivo que reflexivo e acabou exercendo forte influência nas práticas musicológicas das gerações posteriores. Estas trouxeram a público uma parcela significativa do conhecimento sobre o passado musical brasileiro por meio de estudos de compositores e repertórios existentes nos inúmeros acervos de manuscritos musicais. Mesmo com estas importantes contribuições, seus procedimentos musicológicos aportavam-se nos preceitos tradicionais da "descoberta e restauração" de obras; da dissociação texto/contexto, compreendendo a música como uma entidade autônoma; na atividade colecionista e no "princípio de não invasão de domínios" que dificultavam o acesso às fontes por parte de outros pesquisadores. ${ }^{4}$ Alberto Ikeda, no final dos anos 1990, ao avaliar a ideologia positivista da musicologia brasileira, chegou a chamá-la de "paraciência" ou "protociência", uma vez que suas pesquisas

Trata[vam]-se mais de musicografias, ou seja, trabalhos apenas de descrição do objeto estudado ou coleções de músicas e documentos de interesse musical, que propriamente de musicologia, a qual exige análise, interpretação e compreensão dos fatos, além das descrições simples. (IKEDA, 1998, p.64, grifos próprios).

Assim sendo, pode-se dizer que as historiografias da música passaram a ter uma maior preocupação metodológica e um maior respaldo teórico a partir do momento em que se tornaram uma atividade universitária. No campo específico da musicologia histórica, esta inserção acadêmica se deu especialmente na década de 1990, institucionalizando-se enquanto linha de pesquisa, o que possibilitou um maior debate entre pesquisadores e um diálogo mais consciente com outras disciplinas, ampliando as possibilidades interpretativas dos inúmeros fenômenos musicais e estabelecendo, finalmente, a prática de uma nova musicologia no Brasil (CASTAGNA, 2008). Esse contexto inclusive já possibilitou, na perspectiva interdisciplinar, o aparecimento de trabalhos

4 Textos clássicos da musicologia histórica brasileira já problematizaram essas condutas. Ver, nesse sentido, Castagna (1998), Ikeda (1998) e Cotta (1999). 
preocupados com o levantamento e a análise da historiografia da música no Brasil, ${ }^{5} \mathrm{O}$ que, para o contexto específico da música em Santa Catarina, este artigo procura também iniciar.

\section{Santa Catarina no mapa da musicologia}

De maneira semelhante, os esforços empregados para a construção de uma historiografia da música no estado de Santa Catarina, naturalmente, seguiram o mesmo panorama das várias histórias da música no Brasil, isto é, impulsionados de início por estudos realizados fora da área de música e/ou de seu interesse científico. ${ }^{6}$ Com a consolidação da nova musicologia brasileira e o decorrente intercâmbio entre pesquisas e pesquisadores, tornou-se possível problematizar uma literatura musical anterior à fase musicológica e iniciar um trabalho sistemático em arquivos e acervos catarinenses com maior consciência metodológica. Realizado em Curitiba em 1997, o I Simpósio Latino-Americano de Musicologia - e a publicação de seus anais no ano seguinte - fez surgir um importante debate acerca da necessidade de uma feitura mais descentralizada da disciplina no Brasil. A musicóloga Maria Elisabeth Lucas (1998, p.69), ao refletir sobre "as condições do exercício profissional da musicologia de forma regular e contínua", foi quem primeiro chamou atenção para o fato de que as pesquisas musicológicas no país se direcionavam às regiões de "alta visibilidade histórico-documental", com o predomínio de atividades dirigidas aos grandes centros de prática musical brasileira, como foram os eixos Sudeste e Nordeste. Naquele momento, Lucas (1998, p.73) apontava para o potencial de regionalização dos estudos em musicologia histórica, valorizando também as pesquisas nas consideradas "áreas periféricas da sociedade colonial, praticamente ausentes da historiografia musical brasileira", como eram os estados da região Sul, o que permitiria "pensar comparativamente as práticas musicais dessa região", fornecendo dados para o resto do país.

Mesmo com o estímulo decorrente da publicação de Maria Elizabeth Lucas (1998), o quadro de pesquisadores interessados no exercício de uma musicologia histórica local para Santa Catarina continuava escasso, uma vez ainda que a própria disciplina procurava estabelecer seu lugar institucionalmente - assentando-se na Universidade -, dificultando, assim, a realização de novas pesquisas e a consequente construção de um corpus bibliográfico musicologicamente orientado acerca da história da música catarinense. Uma década após o texto seminal de Lucas (1998), o musicólogo Marcos Tadeu Holler (2008) apontava para uma realidade não muito diferente, ainda que promissora, uma vez que, de acordo com o autor, à época, "somente muito recentemente os estados do sul se viram incluídos [no panorama da pesquisa musicológica brasileira]", afirmando ainda que "o estado de Santa Catarina ainda tem muitas fontes sobre sua me- 
mória musical a serem desveladas" (HOLLER, 2008, p.1). Mapeando fontes e levantando trabalhos já publicados sobre a música no estado - reiterando também a importância da integração das pesquisas histórico-musicológicas no sul do Brasil -, Holler (2008, p.3) comenta:

\begin{abstract}
Os textos sobre história da música em Santa Catarina são raros. As obras A música em Santa Catarina no século XIX, de Oswaldo Rodrigues Cabral, e A história da música, de Hélio Teixeira da Rosa, capítulo do livro História sociocultural de Florianópolis, coordenado por Osvaldo Ferreira de Melo, ambas de 1951, apresentam alguns dados, porém sem consistência musicológica. Em Nossa Senhora do Desterro: memória (1972), Oswaldo Rodrigues Cabral dedica um capítulo à história das artes plásticas e da música em Florianópolis desde o séc. XVII [...]. Assim como as obras anteriores, o texto de Oswaldo Cabral é relevante pelas suas referências a algumas das fontes, porém não apresenta conclusões consideráveis (p.3). Como textos mais recentes, podem-se mencionar o trabalho de conclusão de curso da acadêmica Ana Ribamar Braga, "Fontes sobre a história da música em Santa Catarina" (2000) [...] e A vitrola nostálgica, de Marcelo Téo (2007), que aborda aspectos da música em Santa Catarina a partir de uma perspectiva histórica mais coerente do ponto de vista metodológico, e discorre também sobre algumas fontes.
\end{abstract}

$\mathrm{Na}$ tarefa de construir historiografias locais para a música, a articulação entre música, músicos e suas práticas no entorno das cidades e seus estados já vinha e vem sendo retratada com base em vários espaços geográficos do Brasil.7 Neste sentido, gradativamente foram surgindo mais trabalhos científicos preocupados com a história da música das cidades do estado de Santa Catarina, especialmente com vistas à consulta documental. O fato é que, incentivados pelo trabalho de Marcos Holler (2008), perdurando até hoje, foi ao longo do final dos anos 2000 que começaram a aparecer os primeiros trabalhos histórico-musicológicos sobre Santa Catarina inseridos na pesquisa em Música, sobretudo no contexto da capital Florianópolis, a partir principalmente das monografias dos cursos de Graduação em Música da Udesc. ${ }^{8}$ Ainda assim, como uma contribuição direta para a pesquisa em Música, a constituição na universidade do estado do Programa de Pós-Graduação em Música, em nível de mestrado no ano de 2007, determinou um caminho importante para o fomento à temática. Esse período também marca o aumento do interesse de outras áreas de conhecimento, com maior tradição investigativa, pelas manifestações musicais de Santa Catarina, com o aparecimento de uma série de pesquisas de cunho essencialmente histórico, antropológico e/ou socio-

\footnotetext{
7 Ver, por exemplo, Oliveira (1995) acerca da atuação do compositor Lupicínio Rodrigues na boemia musical de Porto Alegre, para citar uma pesquisa da região Sul nos anos 1990. Ou ainda, como espaço de maior visibilidade histórico-documental, Polastre (2008) sobre a música na cidade de São Paulo nos séculos XVIII e XIX, Moraes (2000) e Bessa (2012) para as manifestações musicais no século XX. Todos articularam aspectos musicológicos com o campo da História.

8 Trata-se dos cursos de bacharelado em instrumento e licenciatura, uma vez que Santa Catarina não possui um curso superior voltado para a formação de musicólogos. Com relação às monografias de conclusão, ver: Uller (2008), Freccia (2008), Pires (2008), Debiasi (2008), Santolin (2009), Rosa (2010), Pamplona (2011), Gonçalves (2012), Vieira (2013), Minozzo (2014), Mezzalira (2014), Coelho (2015) e Gruezmacher (2017). Boa parte desses trabalhos resultou também em artigos que foram publicados ao longo dos anos na revista DAPesquisa, do Centro de Artes da Udesc. Theiss (2009) também realizou um trabalho de conclusão de curso de graduação sobre a música em Santa Catarina, defendido no Bacharelado em História da Furb.
} 
lógico, ampliando o número de pesquisadores interessados na temática e os quadros conceituais para sua interpretação. ${ }^{9} \mathrm{E}$ é este o mote de interesse desse artigo.

O levantamento dos dados foi realizado inicialmente no banco de teses e dissertações da Capes e na Biblioteca Digital Brasileira de Teses e Dissertações. Na busca, foi utilizada como entrada a expressão "História da Música em Santa Catarina", que gerou um total de 98 trabalhos. A partir de uma triagem foram priorizadas somente as pesquisas que investigaram a história da música catarinense e suas relações socioculturais como foco principal, sendo assim desconsideradas pesquisas de caráter pedagógico-musical ou historiografias que davam às manifestações musicais do estado importância secundária. A expressão utilizada no mecanismo de busca gerou a confirmação do predomínio de pesquisas oriundas das duas universidades públicas de Santa Catarina - ainda que tenha permitido acessar trabalhos gerados em outros estados -, o que possibilitou também confrontar os trabalhos mapeados no banco de teses e na Biblioteca Digital com os existentes nos repositórios dos programas de pós-graduação dessas universidades, refinando o mapeamento. Versando então sobre a história da música em Santa Catarina, esse percurso levou ao estabelecimento de um total de 28 pesquisas acadêmicas, entre dissertações de mestrado e teses de doutorado, produzidas em programas de pós-graduação em Música e História. Vale ressaltar que o mapeamento exclusivo de teses e dissertações procura estabelecer um contato com trabalhos publicados e já completados no âmbito da pesquisa acadêmica. Aproximar-se de trabalhos de natureza mais diversificada, mesmo os de caráter científico, como artigos, comunicações e anais de congressos ou capítulos de livros - naturalmente existentes -, extrapolaria os limites desse artigo. Outrossim, especialmente no contexto da música em Santa Catarina, a quase totalidade das publicações nesses outros formatos parte da construção ou de recortes das teses e dissertações, sendo elas então os trabalhos que fornecem uma discussão mais ampliada e dados mais aprofundados acerca da temática e das especificidades dos objetos de estudo. Portanto, são listados na Tab. 1 os trabalhos mapeados, do mais antigo ao mais recente. Com exceção da tese de Bernardi (2003), todas as pesquisas encontram-se integralmente disponíveis para consulta eletrônica nos repositórios digitais de suas respectivas universidades de origem.

9 Levando em consideração pesquisas produzidas fora das áreas de conhecimento delimitadas aqui, ver como exemplo significativos Sezerino (2007) para a pesquisa em Sociologia, Eberhardt (2012) para a pesquisa em Patrimônio Cultural ou ainda Spindola (2014) nas Ciências da Linguagem. 


\begin{tabular}{|c|c|c|c|c|c|c|}
\hline \multicolumn{7}{|c|}{ História da música em Santa Catarina na pesquisa acadêmica } \\
\hline Autor(a) & Ano & Título & Palavras-chave & Área & Natureza & Instituição \\
\hline $\begin{array}{l}\text { BERNARDI, } \\
\text { Paulo. }\end{array}$ & 2003 & $\begin{array}{c}\text { Canção do } \\
\text { imigrante italiano: } \\
\text { sua leitura a partir } \\
\text { de uma localidade } \\
\text { rural catarinense } \\
\text { (1996-1999). }\end{array}$ & $\begin{array}{l}\text { 1996-1999. } \\
\text { Música regional. } \\
\text { Canção do } \\
\text { imigrante italiano. } \\
\text { Identidade } \\
\text { regional rural. } \\
\text { Santa Catarina. }\end{array}$ & História & Tese & UFSC \\
\hline $\begin{array}{l}\text { TÉO, } \\
\text { Marcelo } \\
\text { Robson. }\end{array}$ & 2005 & $\begin{array}{c}\text { A vitrola } \\
\text { nostálgica: música } \\
\text { e constituição } \\
\text { cultural em } \\
\text { Florianópolis } \\
\text { (1930-1949). }\end{array}$ & --- & História & Dissertação & UFRGS \\
\hline $\begin{array}{c}\text { SILVA, Áurea } \\
\text { Demaria. }\end{array}$ & 2006 & $\begin{array}{l}\text { No balanço da } \\
\text { "mais querida": } \\
\text { música, } \\
\text { socialização e } \\
\text { cultura negra } \\
\text { na Escola de } \\
\text { Samba Embaixada } \\
\text { Copa Lord - } \\
\text { Florianópolis (SC). }\end{array}$ & $\begin{array}{l}\text { Embaixada Copa } \\
\text { Lord. Copa Lord. } \\
\text { Carnaval de } \\
\text { Florianópolis. } \\
\text { Escola de } \\
\text { samba. Samba e } \\
\text { socialização. }\end{array}$ & Música & Dissertação & Unesp \\
\hline $\begin{array}{l}\text { ROSSBACH, } \\
\text { Roberto } \\
\text { Fabiano. }\end{array}$ & 2008 & $\begin{array}{l}\text { As sociedades de } \\
\text { canto da região } \\
\text { de Blumenau } \\
\text { no início da } \\
\text { colonização alemã } \\
\text { (1863-1937). }\end{array}$ & $\begin{array}{c}\text { Canto coral. } \\
\text { Sociedades de } \\
\text { canto. Imigração } \\
\text { alemã. História da } \\
\text { música em Santa } \\
\text { Catarina. }\end{array}$ & Música & Dissertação & Udesc \\
\hline $\begin{array}{l}\text { MOTA, } \\
\text { Rodrigo de } \\
\text { Souza. }\end{array}$ & 2009 & $\begin{array}{l}\text { Rock dos anos } \\
\text { 1980, prefixo } \\
\text { 48: um crime } \\
\text { perfeito? }\end{array}$ & $\begin{array}{c}\text { Rock. Anos } 1980 . \\
\text { Florianópolis. } \\
\text { Jovens. }\end{array}$ & História & Dissertação & UFSC \\
\hline $\begin{array}{l}\text { FERREIRA, } \\
\text { Júlio } \\
\text { Córdoba } \\
\text { Pires. }\end{array}$ & 2009 & $\begin{array}{c}\text { Reflexões } \\
\text { sobre o choro } \\
\text { enquanto gênero } \\
\text { e musicalidade e } \\
\text { sua presença em } \\
\text { Florianópolis/SC. }\end{array}$ & $\begin{array}{c}\text { Música popular } \\
\text { brasileira. Choro. } \\
\text { Florianópolis. } \\
\text { Santa Catarina. }\end{array}$ & Música & Dissertação & Udesc \\
\hline $\begin{array}{l}\text { BATISTA, } \\
\text { Andrey } \\
\text { Garcia. }\end{array}$ & 2009 & $\begin{array}{c}\text { Frei Bernardino } \\
\text { Bortolotti } \\
\text { (1896-1966) e } \\
\text { a cena musical } \\
\text { em Lages: uma } \\
\text { contribuição para } \\
\text { a historiografia da } \\
\text { música na serra } \\
\text { catarinense. }\end{array}$ & $\begin{array}{c}\text { História da música } \\
\text { em Santa Catarina. } \\
\text { Musicologia } \\
\text { histórica. Música } \\
\text { sacra. }\end{array}$ & Música & Dissertação & Udesc \\
\hline
\end{tabular}




\begin{tabular}{|c|c|c|c|c|c|c|}
\hline $\begin{array}{l}\text { SILVA, } \\
\text { Rodrigo } \\
\text { Moreira da. }\end{array}$ & 2009 & $\begin{array}{c}\text { "Ratoeira não me } \\
\text { prende, que eu } \\
\text { não tenho quem } \\
\text { me solta": música } \\
\text { de tradição oral e } \\
\text { identidade cultural } \\
\text { no litoral de Santa } \\
\text { Catarina. }\end{array}$ & $\begin{array}{l}\text { Ratoeira. } \\
\text { Etnomusicologia. } \\
\text { Identidade } \\
\text { cultural. }\end{array}$ & Música & Dissertação & Udesc \\
\hline $\begin{array}{l}\text { BEZERRA, } \\
\text { Frederico } \\
\text { Freire } \\
\text { de Lima } \\
\text { Neibert. }\end{array}$ & 2010 & $\begin{array}{l}\text { O samba-enredo } \\
\text { em Florianópolis: } \\
\text { perspectivas } \\
\text { históricas } \\
\text { e práticas } \\
\text { composicional } \\
\text { entre membros } \\
\text { da "protegidos da } \\
\text { princesa". }\end{array}$ & $\begin{array}{l}\text { Samba-enredo. } \\
\text { Carnaval. } \\
\text { Florianópolis. }\end{array}$ & Música & Dissertação & Udesc \\
\hline $\begin{array}{l}\text { GUTJAHR, } \\
\text { Simone. }\end{array}$ & 2010 & $\begin{array}{l}\text { Atuação de } \\
\text { músicos em } \\
\text { associações } \\
\text { religiosas de } \\
\text { Desterro nos } \\
\text { períodos colonial } \\
\text { e imperial. }\end{array}$ & $\begin{array}{l}\text { História da } \\
\text { música em Santa } \\
\text { Catarina. Música } \\
\text { em associações } \\
\text { religiosas. Música } \\
\text { nos períodos } \\
\text { colonial e } \\
\text { imperial. }\end{array}$ & Música & Dissertação & Udesc \\
\hline $\begin{array}{l}\text { SANTHIAS, } \\
\text { Paulo } \\
\text { Roberto. }\end{array}$ & 2010 & $\begin{array}{l}\text { Zzzzriguidum! } \\
\text { Consulado: o } \\
\text { choque do samba } \\
\text { em Florianópolis } \\
\text { (memórias e } \\
\text { histórias de uma } \\
\text { Escola de Samba } \\
\text { encravada na } \\
\text { cidade - 1976 a } \\
\text { 2000). }\end{array}$ & $\begin{array}{l}\text { História. Samba- } \\
\text { enredo. Cultura. } \\
\text { Cidade. }\end{array}$ & História & Dissertação & Udesc \\
\hline $\begin{array}{l}\text { MACEDO, } \\
\text { Lisandra } \\
\text { Barbosa. }\end{array}$ & 2011 & $\begin{array}{l}\text { Ginga, Catarina! } \\
\text { Manifestações do } \\
\text { samba em } \\
\text { Florianópolis na } \\
\text { década de } 1930 .\end{array}$ & $\begin{array}{l}\text { Samba. História } \\
\text { de Florianópolis. } \\
\text { História do Tempo } \\
\text { Presente. }\end{array}$ & História & Dissertação & Udesc \\
\hline $\begin{array}{l}\text { SCHNEIDER, } \\
\text { Alexandre da } \\
\text { Silva. }\end{array}$ & 2011 & $\begin{array}{l}\text { Sociedade Musical } \\
\text { Amor à Arte: um } \\
\text { estudo histórico } \\
\text { sobre a atuação } \\
\text { de uma banda } \\
\text { em Florianópolis } \\
\text { na Primeira } \\
\text { República. } \\
\end{array}$ & $\begin{array}{l}\text { Sociedade Musical } \\
\text { Amor à Arte. } \\
\text { Banda de música. } \\
\text { Música em } \\
\text { Florianópolis. }\end{array}$ & Música & Dissertação & Udesc \\
\hline $\begin{array}{l}\text { ONDRUSEK, } \\
\text { Cláudia } \\
\text { Bonaldo. }\end{array}$ & 2011 & $\begin{array}{l}\text { A recepção } \\
\text { de ópera em } \\
\text { Florianópolis. }\end{array}$ & $\begin{array}{l}\text { Ópera. Etnografia. } \\
\text { Recepção. Crítica. }\end{array}$ & Música & Dissertação & Udesc \\
\hline
\end{tabular}




\begin{tabular}{|c|c|c|c|c|c|c|}
\hline $\begin{array}{c}\text { SOUZA, } \\
\text { Marcel } \\
\text { Oliveira de. }\end{array}$ & 2012 & $\begin{array}{c}\text { A voz do } \\
\text { progresso: música } \\
\text { e modernização } \\
\text { nas ondas da rádio } \\
\text { clube de Lages - } \\
\text { SC. }\end{array}$ & $\begin{array}{l}\text { Música de rádio. } \\
\text { Radiodifusão em } \\
\text { Lages. Políticas de } \\
\text { modernização da } \\
\text { nação. }\end{array}$ & Música & Dissertação & Udesc \\
\hline $\begin{array}{l}\text { PIRES, } \\
\text { Débora } \\
\text { Costa. }\end{array}$ & 2012 & $\begin{array}{l}\text { Narciso e Eco: os } \\
\text { periódicos como } \\
\text { reflexos e ecos da } \\
\text { vida musical em } \\
\text { Desterro durante } \\
\text { o Império. }\end{array}$ & $\begin{array}{c}\text { História da } \\
\text { imprensa. História } \\
\text { da música em } \\
\text { Desterro. Música } \\
\text { no século XIX. } \\
\text { História da música } \\
\text { em Santa Catarina. }\end{array}$ & Música & Dissertação & Udesc \\
\hline $\begin{array}{l}\text { MOHR, } \\
\text { Denise. }\end{array}$ & 2013 & $\begin{array}{c}\text { Orquestra de } \\
\text { Câmara São Bento } \\
\text { do Sul, seu público } \\
\text { e seu papel para o } \\
\text { município. }\end{array}$ & $\begin{array}{l}\text { Orquestra de } \\
\text { Câmara São Bento } \\
\text { do Sul. História } \\
\text { da música em } \\
\text { Santa Catarina. } \\
\text { Recepção a } \\
\text { concertos. }\end{array}$ & Música & Dissertação & Udesc \\
\hline $\begin{array}{c}\text { SANTOS, } \\
\text { Scheyla } \\
\text { Tizatto. }\end{array}$ & 2013 & $\begin{array}{l}\text { Nas Manhãs do } \\
\text { Sul do Mundo: } \\
\text { música e cidade } \\
\text { na produção do } \\
\text { grupo Expresso } \\
\text { Rural (1980-2012). }\end{array}$ & $\begin{array}{l}\text { Expresso Rural. } \\
\text { História e Canção. } \\
\text { Canção. História } \\
\text { da Música em } \\
\text { Santa Catarina. }\end{array}$ & História & Dissertação & Udesc \\
\hline $\begin{array}{c}\text { SOUZA, } \\
\text { Marco } \\
\text { Antonio } \\
\text { Ferreira. }\end{array}$ & 2014 & $\begin{array}{c}\text { Entre a cantoria e } \\
\text { a nossa barulheira: } \\
\text { Florianópolis nas } \\
\text { canções do grupo } \\
\text { Engenho e da } \\
\text { banda Dazaranha } \\
\text { (1980-2004). }\end{array}$ & $\begin{array}{l}\text { Florianópolis. } \\
\text { Grupo Engenho. } \\
\text { Dazaranha. } \\
\text { Cidade. }\end{array}$ & História & Dissertação & Udesc \\
\hline $\begin{array}{l}\text { PEREIRA, } \\
\text { Tiago. }\end{array}$ & 2014 & $\begin{array}{l}\text { Pela escuta de } \\
\text { Heinz Geyer } \\
\text { na "cidade } \\
\text { ressoante": Música } \\
\text { e Campanha de } \\
\text { Nacionalização no } \\
\text { cotidiano urbano } \\
\text { de Blumenau - SC } \\
\text { (1921-1945). }\end{array}$ & $\begin{array}{l}\text { Heinz Geyer. } \\
\text { Música em } \\
\text { Blumenau. } \\
\text { Campanha de } \\
\text { Nacionalização. } \\
\text { História da música } \\
\text { em Santa Catarina. } \\
\text { Musicologia } \\
\text { urbana. }\end{array}$ & Música & Dissertação & Udesc \\
\hline $\begin{array}{l}\text { SPROGIS, } \\
\text { Voldis. }\end{array}$ & 2015 & $\begin{array}{l}\text { Voluntários da } \\
\text { música: um } \\
\text { estudo histórico } \\
\text { sobre a atuação } \\
\text { da Banda de } \\
\text { Música do Corpo } \\
\text { de Bombeiros } \\
\text { Voluntários de } \\
\text { Joinville e seu } \\
\text { papel em Joinville } \\
\text { de } 1967 \text { a } 1974 .\end{array}$ & $\begin{array}{l}\text { Banda de música. } \\
\text { História da música } \\
\text { em Joinville. } \\
\text { Movimento } \\
\text { associativo. }\end{array}$ & Música & Dissertação & Udesc \\
\hline
\end{tabular}




\begin{tabular}{|c|c|c|c|c|c|c|}
\hline $\begin{array}{l}\text { CORREA, } \\
\text { Wellinton } \\
\text { Carlos. }\end{array}$ & 2015 & $\begin{array}{c}\text { "Vou andar por } \\
\text { ai": o balanço, a } \\
\text { música e a bossa } \\
\text { de Luiz Henrique } \\
\text { Rosa. }\end{array}$ & $\begin{array}{c}\text { Luiz Henrique } \\
\text { Rosa. Biografia. } \\
\text { Música Popular } \\
\text { Brasileira. Bossa } \\
\text { Nova. }\end{array}$ & História & Dissertação & Udesc \\
\hline $\begin{array}{l}\text { WERLING, } \\
\text { Camila. }\end{array}$ & 2016 & $\begin{array}{c}\text { A música como } \\
\text { representação } \\
\text { dos movimentos } \\
\text { germânicos e não } \\
\text { germânicos em } \\
\text { Blumenau nas } \\
\text { décadas de } 1970 \text { e } \\
1980 .\end{array}$ & $\begin{array}{c}\text { Música em } \\
\text { Blumenau. } \\
\text { Identidade. } \\
\text { Miscigenação } \\
\text { Cultural. História } \\
\text { da Música em } \\
\text { Santa Catarina. } \\
\text { Musicologia } \\
\text { Urbana. }\end{array}$ & Música & Dissertação & Udesc \\
\hline $\begin{array}{l}\text { NEUMANN, } \\
\text { Ricardo. }\end{array}$ & 2017 & $\begin{array}{c}\text { A cena musical } \\
\text { alternativa } \\
\text { norte-nordeste } \\
\text { catarinense entre } \\
1990 \text { e } 2010: \text { das } \\
\text { ruas aos espaços } \\
\text { virtuais. }\end{array}$ & $\begin{array}{c}\text { Cenas. Cena } \\
\text { Alternativa } \\
\text { Norte-Nordeste } \\
\text { Catarinense } \\
\text { entre } 1990-2010 . \\
\text { História Cultural. } \\
\text { Arte e Política. } \\
\text { Espaços Virtuais. }\end{array}$ & História & Tese & UFSC \\
\hline $\begin{array}{l}\text { LIVRAMEN- } \\
\text { TO, Natália } \\
\text { dos Santos. }\end{array}$ & 2017 & $\begin{array}{l}\text { O violão no } \\
\text { samba: um estudo } \\
\text { etnográfico em } \\
\text { Florianópolis. }\end{array}$ & $\begin{array}{c}\text { Etnografia. Violão. } \\
\text { Samba. Música } \\
\text { popular. }\end{array}$ & Música & Dissertação & Udesc \\
\hline $\begin{array}{l}\text { SPESSATTO, } \\
\text { Luiz Fernan- } \\
\text { do. }\end{array}$ & 2017 & $\begin{array}{l}\text { Maestro Alfredo } \\
\text { Sigwalt (1915- } \\
\text { 1994) e a } \\
\text { sociedade de } \\
\text { cultura artística } \\
\text { de Joaçaba e } \\
\text { Herval D'Oeste } \\
\text { (SCAJHO): } \\
\text { contribuições para } \\
\text { a história cultural } \\
\text { de Joaçaba - SC } \\
\text { nas décadas de } \\
1950 \text { a } 1970 .\end{array}$ & $\begin{array}{l}\text { Alfredo Sigwalt. } \\
\text { SCAJHO. } \\
\text { Sociedades } \\
\text { Culturais. Música } \\
\text { de Concerto. } \\
\text { Joaçaba. História } \\
\text { da Música em } \\
\text { Santa Catarina. }\end{array}$ & Música & Dissertação & Udesc \\
\hline $\begin{array}{l}\text { OLIVEIRA, } \\
\text { Carlos Edu- } \\
\text { ardo Pereira } \\
\text { de. }\end{array}$ & 2018 & $\begin{array}{l}\text { Cabe rock nessa } \\
\text { llha? Formação } \\
\text { da cena rock em } \\
\text { Florianópolis } \\
(1980-1989) .\end{array}$ & $\begin{array}{l}\text { Cenas urbanas. } \\
\text { Rock. Espaços } \\
\text { de sociabilidade. } \\
\text { Juventude e } \\
\text { História do Tempo } \\
\text { Presente. }\end{array}$ & História & Dissertação & Udesc \\
\hline $\begin{array}{l}\text { ROSSBACH, } \\
\text { Roberto } \\
\text { Fabiano. }\end{array}$ & 2020 & $\begin{array}{c}\text { Catalogação } \\
\text { sistemática e } \\
\text { descritiva de obras } \\
\text { e fontes musicais } \\
\text { no Brasil: o } \\
\text { catálogo temático } \\
\text { de Heinz Geyer } \\
\text { (1897-1982). }\end{array}$ & $\begin{array}{c}\text { Arquivologia } \\
\text { musical. Catálogo } \\
\text { temático. } \\
\text { Metodologia } \\
\text { catalográfica. } \\
\text { Música em } \\
\text { Blumenau. Heinz } \\
\text { Geyer. }\end{array}$ & Música & Tese & Unesp \\
\hline
\end{tabular}

Tab. 1: Trabalhos mapeados. Fonte: Elaboração do autor. 
Quantitativamente, é a região litorânea e da grande Florianópolis que recebe o maior número de pesquisas, com 17 trabalhos mapeados, do período colonial à modernidade, na perspectiva da musicologia (SILVA, 2006; FERREIRA, 2009; SILVA, 2009; BEZERRA, 2010; GUTJARH, 2010; SCHNEIDER, 2011; ONDRUSECK, 2011; PIRES, 2012; LIVRAMENTO, 2017), à história do tempo presente (TÉO, 2005; MOTA, 2009; SANTHIAS, 2010; MACEDO, 2011; SANTOS, 2013; SOUZA, 2014; CORREA, 2015, OLIVEIRA, 2018). Esse panorama é seguido por três pesquisas sobre o contexto musical da cidade de Blumenau, no Vale do Itajaí catarinense (ROSSBACH, 2008; PEREIRA, 2014; WERLING, 2016) - com um trabalho sistemático sobre um dos músicos da cidade (ROSSBACH, 2020) - , e duas pesquisas sobre a cidade de Lages, na serra catarinense (BATISTA, 2009; SOUZA 2012). Por sua vez, pesquisadores da região norte de Santa Catarina já possibilitaram o mapeamento de fontes de interesse musical nas cidades de São Bento do Sul (MOHR, 2013) e Joinville (SPROGIS, 2015), com um trabalho discutindo também a cena musical na região (NEUMANN, 2017). O oeste do estado apresenta uma pesquisa musicológica sobre a cidade de Joaçaba (SPESSATTO, 2017) e um trabalho historiográfico sobre a música em Concórdia (BERNARDI, 2003), ampliando assim, gradativamente, o corpus de trabalhos científico para além do espaço da capital. Apenas as manifestações musicais das cidades da região sul de Santa Catarina ainda não foram contempladas com pesquisas histórico-musicológicas, estando aí uma lacuna a ser preenchida. Outrossim, vale destacar que, como se constata na Tab. 1, os primeiros trabalhos foram produzidos em universidades fora de Santa Catarina, panorama que se alterou com o aparecimento dos Programas de Pós-Graduação nas universidades públicas do estado. Nesse sentido, atualmente grande parte das pesquisas está vinculada aos programas de pós-graduação da Udesc, que nos trabalhos mapeados determinam $81,5 \%$ da produção total produzida na universidade do estado, seguida pelas produções na universidade federal. Com relação às áreas de concentração, do total de 28 pesquisas, 18 trabalhos (cerca de 64\%) foram produzidos na pesquisa em Música e dez trabalhos na pesquisa em História (cerca de 36\%).

Não obstante, o projeto de construção de uma "história da música em Santa Catarina" - nove trabalhos assumem especificamente essa expressão em suas palavras-chave -, com as suas inevitáveis particularidades, vem sendo constituído na relação entre música, músicos e seus espaços concretos de atuação. Tim Carter (2002, p.10, tradução minha), ${ }^{10}$ ao levantar "modelos para uma musicologia urbana", já assinalava que "não é nenhuma casualidade que o modelo 'música em...' tornou-se (e em muitos casos continua sendo) o preferido" na concepção de pesquisas histórico-musicológicas voltadas a um único lugar e em um momento histórico determinado. E a historiografia da música em Santa Catarina junto à musicologia histórica catarinense cristalizaram o modelo "música em" em várias cidades do estado e em vários tempos da história, marcado por uma orientação fortemente interdisciplinar. E, de fato, a quase totalidade dos trabalhos

10 Original: "It is no coincidence that the 'music in...' model became (and often sitll is) preferred for the design of the doctoral dissertations in musicology that were starting to emerge in large number [...]" (CARTER, 2002, p.10). 
mapeados apresenta uma relação com o espaço da cidade, com muitos já assinalados em seus títulos. Mesmo assim, as cidades não se constituem como objetos de pesquisa, mas em verdade se configuram como um espaço que assenta as práticas musicais e outros enfoques. Sob essa perspectiva, faz-se uma tentativa de situar os trabalhos mapeados com base em diferentes abordagens, a saber: voltados ao estudo em uma perspectiva institucional; dedicados à descrição da trajetória de músicos catarinenses e voltados à descrição de gêneros e movimentos musicais, que assim tecem a história da música em Santa Catarina, interpretada aqui à luz da musicologia.

\section{O enfoque institucional na musicologia catarinense}

Como um dos objetos mais tradicionais da musicologia histórica, a perspectiva institucional está intimamente ligada ao desenvolvimento da prática musicológica no Brasil. Tradicionalmente, esse modelo de estudo se determina na ênfase dada à música praticada em uma instituição - ou em um conjunto delas -, na intenção também de reconstruir seu funcionamento administrativo, seus músicos e personagens significativos, além de mapear os repertórios musicais salvaguardados e eventualmente executados no interior de suas paredes. Torna-se inevitável que, seguindo essa abordagem, os espaços - que, diga-se de passagem, podem ser reais ou imaginários - se consolidem muitas vezes na pesquisa musicológica como espaços isolados, imersos em lugares silenciosos. Ainda assim, a partir do exercício de uma musicologia mais aberta e multidisciplinar, atualmente é reconhecida a necessidade de também historicizar o contexto histórico, social e estético em que as atividades musicais das instituições tomavam lugar. Nessa perspectiva, na musicologia catarinense, destacam-se as pesquisas de Rossbach (2008), Gutjahr (2010), Schneider (2011), Mohr (2013) e Sprogis (2015). Cabe novamente ressaltar que, ainda que os títulos dos trabalhos denotem a música em uma cidade, seguramente ela, no pano de fundo, assenta a vida cultural privada e artística de uma ou um conjunto específico de suas instituições.

Roberto Rossbach (2008) realizou um estudo sobre as sociedades de canto (Gesangvereine) da região de Blumenau - desde o início da colonização da cidade em 1850 até o surgimento da campanha brasileira de nacionalização em 1937 -, definindoas como "coros masculinos amadores que cantavam repertório secular" (p.1) no idioma

alemão. Relata também sobre as sociedades de música, as bandas (Musikvereine), "formadas basicamente por instrumentos de sopro de madeira e metal" (p.86) e ligadas à performance instrumental. Rossbach não se atém ao estudo de uma única sociedade de canto, mas expõe e define características a partir da descrição das ações das sociedades pioneiras, abordando também a circulação desses grupos pelos espaços da cidade, sobretudo nos "salões particulares [...] ou em salões das sociedades de atiradores, onde ocorriam festas promovidas pelas sociedades de canto" (p.94). Essa abordagem voltada à circulação das músicas e músicos dá, portanto, mostras das sonoridades existentes na cidade, sobretudo nos âmbitos institucional e privado. O autor deixa claro ainda que o papel desses grupos artísticos era "manter viva a ligação com a antiga pátria de origem" 
(p.128). Portanto, a música e o canto eram "um pretexto para alcançar o objetivo de reunir grupos de imigrantes e desenvolver uma tendência natural do imigrante em conviver em sociedade" (p.116) e assim "manter o patrimônio cultural dos seus antepassados" (p.128).

Outrossim, no espaço da capital do estado, Simone Gutjahr (2010) realiza uma pesquisa voltada à música sacra e à prática musical das associações religiosas existentes em Desterro durante os séculos XVIII e XIX. Estas associações religiosas, também chamadas de irmandades, "representavam uma possibilidade de atuação para os músicos que fizeram da música a sua fonte de renda" (p.92), consumindo e produzindo-as, a exemplo do Te Deum, de Coutinho, descrito pela musicóloga. A autora ainda levanta e sistematiza alguns dados biográficos e a atuação destes músicos por meio de consultas aos documentos administrativos das irmandades de Desterro e das análises nos periódicos da época, demonstrando que era comum a circulação destes profissionais por mais de uma associação religiosa. Nesse sentido, Gutjahr (2010) é sensível por optar em descrever o contexto histórico de várias irmandades, priorizando três associações religiosas do espaço central de Desterro. Essa abordagem fornece um panorama mais amplo da prática musical desterrense no âmbito religioso, evitando, assim, concepções mais tradicionais que acabam retratando espaços como instituições isoladas e imersas em uma cidade silenciosa. A dissertação da autora serviu de base para o seu recente livro $A$ Música em Desterro (Florianópolis) nos períodos colonial e imperial (GUTJAHR, 2018).

Ainda no espaço de Florianópolis, Alexandre Schneider (2011) retrata a atuação da banda Sociedade Musical Amor à Arte na Florianópolis da Primeira República, entre os anos de 1889 a 1930. O autor busca compreender o papel desta banda, hoje ainda atuante, na sociedade florianopolitana da República Velha. Por meio do estudo dos arquivos da Sociedade Amor à Arte, Schneider conclui que a referida banda, além de formar novos instrumentistas - devido à escassez de escolas de música no início do século $\mathrm{XX}$-, atuou como divulgadora de ideais republicanos e dos diversos gêneros musicais europeus, como as valsas, polcas e mazurcas, além de gêneros latino e norte-americanos, sendo um símbolo da elite da época e formadora do gosto musical da cidade. A pesquisa de Schneider (2011) é um exemplo bastante significativo na concepção de um enfoque institucional na musicologia catarinense, pois dedica-se sobretudo a uma única instituição, procurando, dentro do limite das fontes consultadas, esgotar os dados a ela referentes quanto à sua configuração, sujeitos históricos e funções sociais.

No norte de Santa Catarina, Denise Mohr (2013) aborda a história da Orquestra de Câmara São Bento do Sul desde seus primórdios no início do século XX aos dias atuais, mapeando também a recepção das atividades da orquestra diante de seu público. A autora demonstrou que a orquestra se constitui como “herdeira de uma tradição musical que perdura por 112 anos" (p.99), sendo veículo das preferências musicais dos colonizadores e "uma das principais representações das tradições da cidade" (p.100), vinculadas ao associativismo germânico. Mohr dedica um pequeno espaço para o relato da atuação de outras sociedades são-bentenses, uma vez que essas "não fogem da realidade vivida por muitas outras sociedades fundadas nas regiões próximas, a exemplo das cidades de Blumenau, Joinville e Jaraguá do Sul, onde principalmente a imigração alemã destacou-se" (p.28). A autora apresenta alguns dados de outras sociedades importantes 
para o estabelecimento da Orquestra de Câmara São Bento do Sul. Nesse sentido, a autora reconhece a instituição escolhida como representante fundamental das práticas musicais da cidade, direcionadas então à música orquestral europeia.

Por sua vez, ainda no norte catarinense, Voldis Sprogis (2015) registra a trajetória da Banda de Música do Corpo de Bombeiros Voluntários de Joinville, na segunda metade do século $X X$, com base em consulta documental e em relatos da história oral, colhidos em entrevistas junto de ex-integrantes da banda analisada. Trazendo aspectos da história, o autor mostra que a banda, de perfil "amador e voluntário" (p.71), era formada nos primeiros anos do século XX por "músicos locais que exerciam atuação musical compartilhada em alguns grupos do meio musical joinvilense" (p.72). Nesse sentido, o autor contextualiza brevemente a atuação de outros grupos musicais da cidade, como a banda militar e algumas sociedades recreativas, demonstrando a circulação dos músicos. Ademais, Sprogis (2015) apresenta fontes que comprovam que, após um hiato, a retomada das atividades da banda no final dos anos 1960 se justificava por "conectar a Banda de Música diretamente com o passado", reatando "uma antiga tradição, que viria a somar-se ao universo das comemorações" (p.83), referindo-se ao movimento associativista.

É fato que determinados aspectos aproximam os trabalhos já produzidos e voltados às instituições musicais das cidades de Santa Catarina. Gutjahr (2010) e Schneider (2011) possuem o espaço da capital como ponto de convergência, descrevendo a configuração de importantes instituições produtoras de músicas - sacras e seculares - no tecido urbano de Florianópolis, complementando-se quanto aos recortes temporais. Outrossim, por se debruçarem no estudo de práticas musicais em instituições de cidades de colonização predominantemente alemã, as buscas pela sensação de segurança e pertencimento ao lugar, através da manutenção das tradições musicais e a continuidade de uma cultura específica, são características que estão bastante evidenciadas e conectam os trabalhos de Rossbach (2008), Mohr (2013) e Sprogis (2015).

Nesse sentido também é possível dizer que, em uma perspectiva musicológica, o estudo de instituições musicais em Santa Catarina até o momento é predominantemente secular - diferente do panorama histórico-musicológico de outras regiões do Brasil que possuem maior produção voltada às instituições sacras - e marca uma particularidade da história cultural do estado que denota importância significativa aos agrupamentos musicais, manifestados nas inúmeras sociedades artísticas nas quais músicas e músicos circulavam. Mais importante ainda é perceber que, mesmo determinando instituições musicais centrais no cenário cultural das cidades de Santa Catarina estudadas, os vários trabalhos mapeados demostraram que se tornam inevitáveis o debate e a procura pela relação com outras instituições supostamente "menores" ou "periféricas" e que muitas vezes determinam o surgimento e o fortalecimento das instituições consideradas mais tradicionais. As pesquisas já realizadas, e certamente as que ainda estão por vir, contribuem nesse processo de construção de um mapa institucional das cida- 
des catarinenses, que ajuda a explicar a existente rede de participação e circulação de músicos, a produção e recepção de músicas e toda a história de práticas que marcam a atividade musical do nosso estado.

\section{Músicos no espaço das cidades de Santa Catarina}

Na pesquisa musicológica já é consolidada a abordagem voltada ao estudo da trajetória e da produção musical de personagens específicos em um lugar e em período histórico determinado, ao qual se convencionou chamar de "vida e obra". Os métodos mais tradicionais, ditos positivistas, trouxeram à tona suntuosas quantidades de informação biográfica, mapearam obras e produziram edições críticas - sem necessariamente ocupar-se com estratégias interpretativas mais sociocontextuais -, favorecendo, assim, a consagração das "grandes obras" e a consolidação dos cânones na história da música. Mas "quem pensaria em evocar uma viagem sem ter uma ideia da paisagem na qual ela se realiza?", perguntava-se Bourdieu (1996, p.190), em sua "ilusão biográfica", ao refletir sobre o papel do sujeito na história. Com o estabelecimento da nova musicologia e ainda com a chamada virada pós-moderna, uma história social da música passou a compreender a necessidade de analisar o músico não apenas como produtor de repertório e indivíduo independente, mas como um elemento integrador e pertencente a uma comunidade. O musicólogo Miguel Ángel Marín (2014), ao problematizar a perspectiva urbana do "músico em sociedade", apontou para "o estudo do 'modo de vida' dos músicos" como questão central para compreender "como se integram no tecido social e urbano da cidade, e em que medida essa integração determina sua vida social, profissional, religiosa ou mesmo musical" (p.20). E, na musicologia histórica catarinense, esse enfoque se faz evidente sobretudo nas pesquisas de Batista (2009), Pereira (2014) e Spessatto (2017), enquanto os trabalhos de Santos (2013), Souza (2014) e Correa (2015) configuram esse enfoque na pesquisa em História.

Andrei Batista (2009) realiza uma historiografia musical da serra catarinense, com foco no município de Lages e na figura do Frei Bernardino Bortolotti (1896-1966). Para investigar "aspectos da trajetória e da obra musical do frei" (p.19), o autor desenvolve um interessante caminho de pesquisa. De início, Batista apresenta "aspectos históricos e contextuais" (p.20) de Lages - o "cenário" - em meados do século XX, descrevendo a configuração e a atuação dos vários grupos musicais e por quais instituições da cidade circulavam. É após a problematização do contexto que o musicólogo busca "desenhar uma trajetória biográfica do personagem" (p.74), descrevendo a atuação do franciscano e aspectos estéticos de sua obra musical, para, finalmente, traçar o "perfil individual do personagem e da sua atuação como sujeito socialmente inserido" (p.20). Nesse sentido, para o autor, o padre franciscano ocupava uma posição central no cenário musical e político da cidade, por meio de suas atuações como músico, regente e compositor. Batista faz uso dos registos documentais preservados nos inúmeros acervos de Lages, tendo encontrado seu grande corpus de pesquisa nos arquivos eclesiásticos. A pesquisa de Batista (2009) e o trabalho de Gutjahr (2010) são os únicos trabalhos mapeados que 
problematizam aspectos e personagens da música sacra catarinense.

Outrossim, em 2014 pude concluir uma pesquisa acerca das sonoridades musicais do cotidiano urbano de Blumenau a partir da "escuta" do maestro e compositor Heinz Geyer (1897-1982) em meio à Campanha de Nacionalização, nas primeiras décadas do século XX (PEREIRA, 2014). Assim como Batista (2009), procurei também inicialmente colocar o "sujeito em contexto", descrevendo então o "ideal urbano de Blumenau" a partir dos planos físico e sonoro da cidade, além de suas principais instituições culturais, algumas pelas quais o maestro Geyer circulava, para então problematizar "a escuta de um sujeito" (p.129), que entendi como sendo uma "escuta nacionalizada" (p.132). Ademais, seguindo os pressupostos teórico-metodológicos da chamada musicologia urbana, e dentro do limite das fontes encontradas, procurei mapear a paisagem sonora urbana também dos espaços públicos da cidade - espaços esses ainda negligenciados na historiografia da música - em tempos da Campanha de Nacionalização, em eventos que "tinham a tarefa de nacionalizar também pelos ouvidos" (PEREIRA, 2014, p.118). Não era intenção realizar uma biografia do maestro, mas, entendendo-o como sujeito representativo no cenário musical de Blumenau, a partir de sua atuação e trajetória, desenvolver uma escuta da cidade. Recentemente, a produção musical de Heinz Geyer serviu de base para elaboração de uma metodologia para a catalogação sistemática e descritiva de obras e fontes musicais no Brasil, na tese recém-defendida por Roberto Rossbach (2020).

Por sua vez, Luiz Spessatto (2017) traz contribuições para a história cultural de Joaçaba, a partir do estudo da Sociedade de Cultura Artística de Joaçaba e Herval D'Oeste (SCAJHO) e da atuação do maestro Alfredo Sigwalt (1915-1994) nesse espaço, na segunda metade do século XX. Nesse sentido, o autor apresenta algumas facetas do maestro que, para além de atuar na condução da orquestra e coral da sociedade formados por músicos amadores que vinham de Joaçaba e cidades vizinhas -, atuava também como compositor e professor. Assim, o "Seu Alfredo" utilizava "sua experiência como instrumentista e compositor para criar e adaptar reduções próprias para o grupo que dispunha" (p.48), além de criar "apostilas de musicalização, com orientações para que os estudantes pudessem ter acesso a uma experiência diferenciada de escuta do repertório erudito" (p.50) - tal realidade não era muito diferente da vivida por Heinz Geyer no contexto de Blumenau. O autor também contextualiza as sociedades antecessoras à SCAJHO e ao estabelecimento do maestro na cidade, que passaram a "oportunizar o agrupamento de músicos que tinham interesse em manter suas tradições musicais" (p.85). Nessa perspectiva, para o autor, o maestro Alfredo Sigwalt notabilizou-se em sua atividade para além de sua qualificação musical, em função de ser também "qualificador da germanidade" (p.86), propagando os costumes e preferências do grupo social que fez parte. A pesquisa de Spessatto (2017) é bastante interessante na medida em que expõe a prática de um músico específico em um espaço exclusivo, combinando estratégias da pesquisa histórico-musicológica de caráter biográfico com a abordagem institucional.

Não obstante, com base na canção, os trabalhos de Santos (2013), Souza (2014) e Correa (2015) mapeiam as músicas populares urbanas produzidas e circuladas, sobretudo, no contexto da região de Florianópolis na segunda metade do século XX, na 
perspectiva da história do tempo presente. Scheyla Tizatto Santos (2013) discute a produção sonora dos músicos integrantes da banda Expresso Rural, situando-os a partir de seu disco mais representativo Nas Manhãs do Sul do Mundo, lançado em 1983. A partir de uma análise das canções, a autora identifica as sonoridades do grupo como pertencentes ao que chama de "rock rural", "uma vez que as mensagens presentes nas composições propunham um embate entre campo e cidade com uma intenção bucólica, nostálgica e saudosista" (p.122). Marco Antonio de Souza (2014) propõe escrever uma história da capital entre os anos 1980 a 2004 "a partir das canções de dois dos seus artistas mais significativos, o Grupo Engenho e a banda Dazaranha, com os temas referentes à cidade que os dois conjuntos trataram em suas obras" (p.139). O autor assume, nesse sentido, que seu trabalho "trata-se de um estudo sobre a cidade a partir do trabalho das bandas, mais do que uma análise das canções dos grupos" (p.15), mesmo que acabe evidenciando a produção musical dos músicos escolhidos, de certa forma entendidos - junto ao Expresso Rural - como os representantes da música catarinense na indústria fonográfica. Por sua vez, Wellinton Correa (2015) realiza uma "biografia da vida pública de Luiz Henrique Rosa" (p.30) entre as décadas de 1960 e 1970, músico da capital vinculado ao movimento da bossa nova catarinense. O historiador dá mostras da produção artística do músico, situando-a a partir das redes de sociabilidade de Luiz Henrique Rosa e seus trânsitos pelos lugares dentro e fora do país onde o movimento e os músicos da bossa nova circulavam.

Ainda está por se constituir uma história dos músicos de Santa Catarina. Musicólogos e historiadores interessados nos estudos biográficos, ou orientados nos modos de vida dos músicos catarinenses, ainda encontram barreiras no acesso às fontes - natural em um estado que ainda possui poucos acervos sistematizados -, muitas vezes preservadas nos arquivos particulares, de difícil acesso. Ainda que ao longo do tempo os trabalhos sob esse enfoque tenham sido bastante difundidos como literatura ficcional ou atrelados a uma musicologia positivista, centrados muitas vezes no indivíduo, na cronologia, no relato coerente, único e, sobretudo, totalizante, nas pesquisas mapeadas se percebe uma busca pela superação desse modelo narrativo. A noção de trajetória, que Bourdieu (1996) entendia como uma "série de posições sucessivamente ocupadas por um mesmo agente (ou um mesmo grupo) num espaço que é ele próprio um devir, estando sujeito a incessantes transformações" (p.189), ajuda a aproximar as pesquisas dos autores aqui agrupados. As trajetórias musicais do Frei Bernardino Bortolotti, de Heinz Geyer, Alfredo Sigwalt e Luiz Henrique Rosa, bem como dos músicos do Grupo Engenho e das bandas Expresso Rural e Dazaranha, são assim construídas na pesquisa acadêmica dentro de seus espaços institucionais, ao lado dos agentes de suas coletividades e de seus entornos culturais mais amplos, que os colocavam como personagens importantes para o desenvolvimento da vida musical de suas cidades. Nesse sentido, nota-se que essa abordagem teórico-metodológica, para os pesquisadores interessados, se faz possível na relação entre os pressupostos gerados a partir da nova musicologia com as correntes da nova história, sobretudo a história cultural, social e urbana. 
Mesmo assim, o modo de vida, a trajetória, a produção musical e a circulação dos músicos ainda podem ser amplamente explorados pela musicologia histórica catarinense, dando luz e ecos a sujeitos e espaços ainda silenciados da nossa historiografia musical.

\section{Gêneros e movimentos musicais catarinenses pela pesquisa docu- mental}

A noção tradicional de "música autônoma" na pesquisa histórico-musicológica desde o aparecimento das correntes da nova musicologia vem sendo desenvolvida paralelamente às pesquisas voltadas ao processo de "contextualização" de uma obra, gênero ou produção musical, absorvendo aportes teóricos e princípios metodológicos de áreas como a História e a Sociologia. A ênfase na interpretação da música com base em seus cenários de produção, consumo e recepção - ao que Hooper (2006) chamaria de "mediação" - vem acarretando, no contexto catarinense, trabalhos que trazem à tona múltiplos contextos socioculturais nos quais a música do estado se insere ou se inseriu. Neste sentido, destacam-se as dissertações produzidas por Pires (2012), Souza (2012) e Werling (2016), que em seus trabalhos se interessaram pela análise de práticas musicais desenvolvidas em Santa Catarina nos períodos que abrangem desde o Império à Modernidade a partir de um mapeamento de fontes de natureza majoritariamente arquivística. Além desses, no campo da História e com vistas às manifestações musicais do estado no século XX, situam-se os trabalhos de Bernardi (2003), Téo (2005), Mota (2009), Santhias (2010), Macedo (2011), Neumann (2017) e Oliveira (2018).

Débora Pires (2012) retrata o passado musical da antiga Desterro com olhares voltados aos periódicos da capital que circulavam no século XIX, entre 1831 e 1889. Pires debate e assume os periódicos - jornais, revistas, boletins - como fonte para pesquisa musicológica, analisando os jornais preservados na Biblioteca Pública do Estado de Santa Catarina. A autora aponta que "os jornais desterrenses testemunharam [o] movimento de artistas, de música e de gostos que, ao mesmo tempo, opinavam e expressavam as preferências" (p.118), sendo veículos de comunicação das inúmeras transformações musicais e sociopolíticas da época. Assim, a "vida musical" da capital imperial do estado se descreve com base no anúncio, na descrição e na crítica dos eventos musicais destacados pelos periódicos. Chamo atenção sobretudo para as sonoridades carnavalescas descritas pela autora, que dão indícios também da prática musical nos espaços públicos da cidade - e que pode encontrar no jornal sua fonte de descrição - somando-se às práticas e repertórios mais tradicionais do plano privado, institucionalizado.

Marcel Oliveira de Souza (2012) realiza uma pesquisa musicológica sobre a música de rádio veiculada no âmbito da radiodifusão. $\mathrm{O}$ autor desenvolve o termo música de rádio como categoria analítica, entendendo-o como sendo "o repertório que atua compondo a programação das estações radiofônicas" (p.13). Nesse sentido, por meio de análises de fonogramas e de documentação iconográfica, Souza determina o repertório da Rádio Clube de Lages, na serra catarinense, entre as décadas de 1940 e 1950, como seu objeto de estudo, refletindo sobre os diferentes gêneros musicais em voga no período, 
sobretudo a música sertaneja, e o cast de artistas que marcaram e produziram a música veiculada. O autor situa sua pesquisa "no campo dos estudos de música e mídia, atuante nas áreas da musicologia, da história, da antropologia, da comunicação, da sociologia, entre outras" (p.14), apontando, sob o exemplo lageano, como o rádio se tornou em meados do século passado uma ferramenta para o progresso e constituição de um ideal nacional, além de um sistema eficiente de produção e disseminação de música.

Camila Werling (2016), mesclando a pesquisa documental e a história oral, discute acerca do "cenário musical blumenauense, baseado nas práticas musicais então estabelecidas nas décadas de 1970 e 1980" (p.21). A autora procurou "compreender de que forma a música participou dos processos de reconstrução e manutenção do imaginário social germânico" e do que chamou de "negação à cultura não germânica na cidade" (p.21). Neste sentido, Werling situa movimentos artístico-culturais entendidos como "periféricos" na Blumenau dos anos 1970 e 1980, como as práticas das escolas de samba, os desfiles de carnaval e o cenário do rock, apontando também para a passagem de artistas vinculados à indústria fonográfica e à música popular urbana e também uma posterior "retomada da cultura alemã", sobretudo "nas regiões de potencial turístico da cidade" (p.111). A pesquisa de Werling adquire sentido à medida que vai fazendo "ressoar os sons silenciados na história musical do município" (p.124), ampliando o espectro de movimentos culturais e práticas musicais já então historiografadas na pesquisa em Música sobre Blumenau.

Para a pesquisa histórico-musicológica, é possível estabelecer conexões entre os caminhos das dissertações realizadas por Souza (2012) e Werling (2016), uma vez que ambos realizam o mapeamento das fontes no trabalho arquivístico a partir do estabelecimento dos seus contextos de prática musical: Souza na música de rádio em Lages e Werling nos movimentos de tradição não germânica em Blumenau. Pires (2012), aparentemente, realiza um caminho metodológico diferente, pois determina a fonte de pesquisa - os periódicos que circulavam na antiga Desterro - como seu objeto de interesse histórico-musicológico e dele faz emergir um conjunto de práticas musicais e os ambientes no qual existiram. Mesmo sem pôr em questão como o significado social se reflete nos repertórios levantados, Souza (2012) e Werling (2016) chegam às fontes pela música, Pires (2012) encontra a música a partir das fontes.

Por sua vez, a relação da pesquisa em história com o que se pode chamar de "música de concerto" - objeto de estudo raramente escolhido pelo historiador - em Santa Catarina fica marcada nas produções de Bernardi $(2003)$ e Téo $(2005,2007)$. Paulo Bernardi (2003) debate a canção do imigrante italiano a partir das relações entre aquelas cantadas pelos imigrantes no século XIX e aquelas cantadas pelos seus descendentes em Concórdia, no final do século XX, dando mais uma mostra - tal qual os trabalhos descritos no enfoque institucional - da relação de devotamento às práticas culturais e repertórios dos colonizadores das várias regiões do estado. Esse saudosismo também se faz presente na pesquisa de Marcelo Téo $(2005,2007)$, ao tratar de "uma das histórias da música possíveis em Florianópolis na primeira metade do século XX" (2007, p.26), a partir do deslindamento do cotidiano social e cultural da elite local florianopolitana 
entre os anos de 1930 e 1940. O autor demonstrou de que forma a capital catarinense se constituiu musical e culturalmente também enquanto um "terreno antimoderno" (p.197), ao lembrar, pela metáfora da vitrola nostálgica, que naquelas "terras de areia e mar" (p.223) "o que ela tocava pra valer eram os discos do vovô. Só gente do outro lado do mar, branca e morta" (p.236), isto é, as práticas e os repertórios vinculados à tradição da música europeia.

Não obstante, a "música popular urbana" - entendida aqui na perspectiva de Vinci de Moraes (2000b) como aquela oriunda da cidade moderna, associada "imediata e irreversivelmente aos meios de comunicação e ao mercado" (p.216) - marca os trabalhos de Santhias (2010) e Macedo (2011), que se debruçam sobre o samba e suas manifestações em Santa Catarina, especificamente em Florianópolis. Paulo Santhias (2010) investiga a trajetória da Escola de Samba Consulado a partir da década de 1970, de forma que a descrição de um contexto institucional emerge como estratégia de deslindamento das práticas em torno de um gênero que caminha à margem dos movimentos culturais entendidos como tradicionalmente catarinenses. Outrossim, como um trabalho importante para mapear o aparecimento das práticas em torno do samba no estado, Lisandra Barbosa Macedo, em seu "Ginga, Catarina!" (2011), discute sobre as manifestações do samba na Florianópolis dos anos 1930, a fim de "compreender como o samba se difundiu na cultura popular da capital de Santa Catarina, a partir do período em que o mesmo se consolidava como gênero nacional" (p.135). A autora aponta para o fato de que a cultura do samba se propagou pela capital pela "intensa circulação de músicos e artistas dentro das diversas formas e espaços de entretenimento da cidade" (p.138), também gerada em função do incipiente mercado fonográfico e chegada tardia de emissoras de rádio locais que veiculariam o gênero.

Também são existentes os trabalhos interessados na história da música rock já produzida em Santa Catarina - objeto que, por sua vez, a pesquisa em Música ainda não se dedicou -, por meio das contribuições de Mota (2009), Neumann (2017) e Oliveira (2018). Ao perguntar "se cabe rock nessa ilha" (OLIVEIRA, 2018), ilha essa que constitui um espaço determinado, o "Mundo 48" (MOTA, 2009), Carlos Eduardo de Oliveira e Rodrigo Mota discutem a configuração da música rock na região da capital na década de 1980, respectivamente, na perspectiva de seus espaços de socialização e suas bandas formadoras. Ademais, Ricardo Neumann (2017) investiga a história do que chamou de cena musical alternativa norte-nordeste catarinense, entre 1990 e 2010, formada por bandas autorais independentes. $O$ autor apresenta um quadro interessante que mostra uma cena - que na era digital procura manter-se viva - formada por quarenta bandas vinculadas ao movimento punk e ao rock alternativo, ampliando o espaço historiografado da música rock para além da região de Florianópolis. Essa premissa aponta para a necessidade e a importância do aparecimento de mais pesquisadores interessados nos movimentos musicais marginalizados e espalhados por Santa Catarina, fortalecendo também a escrita de uma história da música popular catarinense.

\section{Gêneros e movimentos musicais catarinenses na interseção com a etnomusicologia}


É consenso que a interdisciplinaridade caracteriza uma orientação pós-moderna no exercício atual da pesquisa acadêmica, o que no campo da Música surge no diálogo com suas próprias subáreas ou no intercâmbio consciente com os tantos outros saberes do conhecimento científico. Nessa perspectiva, a Antropologia se caracteriza como campo importante também na produção de pesquisas sobre a música catarinense. Vale apontar os trabalhos produzidos por Córdova (1991) sobre o sistema cancional do ritual do Terno de Reis em Florianópolis; Souza $(1998,2009)$ sobre os movimentos rap e hip hop na capital; Jacques (2007) sobre a Comunidade Rock e as bandas independentes em Florianópolis; Marcon (2009) sobre a música nativista em Lages; Scoz (2011) sobre a música rap em Blumenau; Hoffmann (2011) sobre o sistema musical Xokleng de Ibirama e Silva (2012) sobre o samba e o choro em Florianópolis. Como ponto de encontro entre a Antropologia e a Música, a etnomusicologia também vem contribuindo na constituição das várias histórias das músicas. Nicholas Cook (2006) já percebia a gradativa prática de uma "musicologia mais inclusiva" (p.11), sobretudo com o processo que chamou de "um tipo de 'etnomusicologização' da disciplina" (p.10). Ainda que haja uma discussão sobre os aspectos terminológicos - ver, por exemplo, a reflexão acerca do prefixo "etno" promovida por Acácio Piedade (2010) -, é nítida a influência positiva que os métodos da etnomusicologia exercem naqueles que dizem realizar uma musicologia histórica. No encontro entre essas duas disciplinas - uma só musicologia? -, e com base nas manifestações musicais de Santa Catarina, destacam-se as pesquisas produzidas no campo da Música por Silva (2006), Silva (2009), Ferreira (2009), Bezerra (2010), Ondrusek (2011) e Livramento (2017).

Rodrigo Silva (2009) e Natália Livramento (2017) são autores que assumem a etnografia como método para o trabalho de campo em suas dissertações, assentando-as então na etnomusicologia como "campo disciplinar" (SILVA, 2009 p.11). Silva discute os aspectos musicais e socioculturais da Ratoeira, "manifestação tradicional da cultura do litoral de Santa Catarina" (p.14). Por sua vez, Livramento (2017) realiza "um estudo acerca do violão e de seus agentes nas práticas musicais de samba" (p.157) em Florianópolis. Mesmo interessados em práticas musicais atuais - com toda a usual densidade de uma etnografia -, ambos os autores são generosos, procurando também apresentar "informações históricas" (SILVA, 2009 p.125), revisitando "os tempos de outrora" (LIVRAMENTO, 2017 p.25) de seus objetos de estudo. Isso dá mostras de que musicologia (histórica) e etnomusicologia, sobretudo no que diz respeito ao estudo da música em Santa Catarina, devem continuar coexistindo, atuando de mãos dadas.

Por sua vez, a escolha metodológica de Áurea Silva (2006) para seu estudo sobre a música na escola de samba Embaixada Copa Lord de Florianópolis foi a "observação participante" (p.14), somada a entrevistas com integrantes da agremiação. Enfatizando o princípio interdisciplinar, a autora procurou com seu estudo "estabelecer vínculos com aspectos apresentados por pesquisas de orientação sociológica e antropológica em relação ao contexto social e cultural das escolas de samba em geral" (p. 16), revelando o papel da Embaixada como um dos "espaços para o encontro da população negra da cidade" (p. 64). Silva (2006) demonstrou que, diferentemente do contexto carioca, 
"em Florianópolis, as escolas de samba - e de certa forma as manifestações afro-brasileiras em geral - não são reconhecidas no cenário da identidade local" (p.74), vinculada a uma imagem de cultura predominantemente açoriana, de forma que sua pesquisa diga-se de passagem a primeira sobre Santa Catarina na pesquisa em Música - lança luz em práticas e grupos sociais/identitários invisibilizados da narrativa oficial.

Enfoque metodológico similar está na pesquisa de Cláudia Ondrusek (2011) sobre a recepção de ópera em Florianópolis. A autora também assume uma "observação participante", porém "combinada à contemplação do passado" (p.10), além de entrevistas. Ondrusek mostra por meio do "processo de garimpagem em jornais da cidade" (p.18) que, diferente do que o circuito operístico atual acredita, houve montagens de ópera em Florianópolis desde o século XIX até meados do século XX, comentando a existência de óperas de compositores radicados na capital, "como as operetas Os namorados de minha mulher e O Ermitão de Muquém, de José Brazilício, e Jardim Maravilhoso, de Álvaro Ramos" (p.71), o que pode ampliar ainda mais as pesquisas já recorrentes sobre a música no contexto da capital do estado.

Júlio Ferreira (2009), por sua vez, realiza um estudo sobre o choro como manifestação de uma musicalidade. O autor procura inserir no mapa da "historiografia da música popular brasileira" o contexto musical e as ocorrências do gênero choro na Florianópolis a partir da década de 1970 aos anos 1980. Sua pesquisa é interessante por assumir uma abordagem híbrida, situando-se "entre a musicologia histórica, a etnomusicologia e os estudos da música popular" (p.19), realizando análises bibliográficas e de documentação musical de caráter audiovisual, como CDs, fitas cassete e vídeos de programas de televisão. O estabelecimento das fontes de pesquisa do autor é exemplo do quanto também as fontes oriundas das novas mídias - para além da partitura - podem contribuir significativamente com a pesquisa musicológica, sobretudo em Santa Catarina, onde, sensatamente, lembrava o autor no final da primeira década dos anos 2000: "Não devemos ter vergonha de tratar 'do factual, do documental, do verificável e do positivista'" (p.21), isto é, prosseguir com o necessário trabalho sistemático nos arquivos. E os esforços nesse sentido vêm continuando.

Outrossim, um hibridismo metodológico também se faz presente na pesquisa de Frederico Bezerra (2010), que entrecruza dois métodos de investigação, o da "pesquisa histórico-documental" e a "abordagem etnográfica" (p.6), para avaliar o samba enredo em Florianópolis entre os membros da Escola de Samba "Protegidos da Princesa", somando-se aos esforços de Silva (2006), Santhias (2010) e Macedo (2011), que também se interessaram pelo gênero. $O$ trabalho do autor se configura também como um exemplo de pesquisa musicológica no qual um gênero musical é problematizado a partir dos seus cenários de produção e prática no contexto institucional. A contribuição de Bezerra, bem como de todos os demais autores que aproximam a musicologia da etnomusicologia, ou que abraçam a perspectiva histórica na abordagem etnográfica, acaba por ampliar o entendimento da música como cultura e assegurar na história da música de Santa Catarina a presença de práticas musicais do estado por vezes negligenciadas da historiografia - escovando a história a contrapelo, como diria W. Benjamin - e que 
podem ainda ser amplamente exploradas e mais ainda visibilizadas, sobretudo na pesquisa em Música.

\section{Algumas considerações}

Em Santa Catarina, as antigas bibliografias de cunho literário-musical possuem um papel determinante na escrita de sua história da música, sendo dotadas de um importante pioneirismo, fator que contribuiu para a realização de pesquisas musicais ulteriores, então de caráter científico. Como foi possível perceber, estas pesquisas foram realizadas por meio do vínculo com programas de pós-graduação das universidades, majoritariamente na Universidade do Estado de Santa Catarina, que vem dando abertura ao desenvolvimento de trabalhos dessa natureza e consolidando-se como um importante núcleo de debate acadêmico sobre a música catarinense. Assim sendo, é possível constatar que a pesquisa histórico-musicológica do estado, na sua trajetória já percorrida, esteve por bastante tempo justificada na necessidade de sua inserção no mapa da musicologia histórica brasileira, como chamavam atenção Lucas (1998) e Holler (2008). Nesse sentido, o argumento desses musicólogos, fundamental à época, tornara-se uma espécie de mantra necessário às justificativas dos trabalhos que foram surgindo gradativamente, especialmente na pesquisa em Música. Essa premissa coloca em questão o fato de que no panorama atual se faz importante encontrarmos outros porquês, afinal hoje pode-se dizer que a pesquisa histórico-musicológica em Santa Catarina está consolidada e inserida na agenda da pesquisa em Música no Brasil. O somatório das forças das ciências humanas para a consolidação de uma historiografia da música em Santa Catarina indica que talvez agora seja o momento de dar um passo adiante, passo esse que apenas o debate entre os pesquisadores interessados pode estabelecer. Por fim, é possível dizer que, de maneira bastante feliz, nos últimos anos vários pesquisadores dedicaram-se e continuam se dedicando - dentro das possibilidades e poucas iniciativas de fomento à pesquisa - ao estudo das realidades musicais específicas das cidades catarinenses, mapeando acervos, levantando memórias, realizando etnografias, descrevendo fontes e tradições de interesse musical, levantando dados e buscando refletir acerca deles, contribuindo, assim, genuinamente para o estabelecimento de uma literatura musicológica dedicada às práticas culturais do nosso estado. Todos os trabalhos mapeados no âmbito da pesquisa acadêmica contribuem significativamente na busca pelo costurar dos pedaços dessa grande teia que é a escrita da história da música em Santa Catarina.

\section{Referências}

BAIA, Silvano. A historiografia da música popular no Brasil: análise crítica dos estudos acadêmicos até o final do século XX. Uberlândia: Ed. UFU, 2015.

BATISTA, Andrey Garcia. Frei Bernardino Bortolotti (1896-1966) e a cena musical 
em Lages: uma contribuição para a historiografia da música na serra catarinense. Dissertação (Mestrado em Música - Musicologia/Etnomusicologia) - Universidade do Estado de Santa Catarina, Florianópolis, 2009.

BERNARDI, Paulo. Canção do imigrante italiano: sua leitura a partir de uma localidade rural catarinense (1996-1999). Tese (Doutorado em História) - Universidade Federal de Santa Catarina, Florianópolis, 2003.

BESSA, Virgínia de Almeida. A cena musical paulistana: teatro musicado e canção popular na cidade de São Paulo (1914-1943). Tese (Doutorado em História) Universidade de São Paulo, São Paulo, 2012.

BEZERRA, Frederico Freire de Lima Neibert. O samba-enredo em Florianópolis: perspectivas históricas e práticas composicional entre membros da "protegidos da princesa". Dissertação (Mestrado em Música - Musicologia/Etnomusicologia Universidade do Estado de Santa Catarina, Florianópolis, 2010.

BLOMBERG, Carla. Histórias da Música no Brasil e Musicologia: uma leitura preliminar. Projeto História: Revista do Programa de Estudos Pós-Graduados de História, Pontifícia Universidade Católica de São Paulo. São Paulo, n. 43, p. 415-444, dez. 2011.

BOURDIEU, Pierre. A ilusão biográfica. In: FERREIRA, M. M.; AMADO, J. (coord.). Usos \& abusos da história oral. Rio de Janeiro: Editora da Fundação Getulio Vargas, 1996 [1986]. p. 183-191.

CABRAL, Oswaldo. A música em Santa Catarina no século XIX. Florianópolis: Instituto Histórico e Geográfico de Santa Catarina, 1951.

CARTER, Tim. The sound of silence: models for an urban musicology. Urban History, v. 29, p. 8-18, 2002.

CASTAGNA, Paulo. "Descoberta e restauração": problemas atuais na relação entre pesquisadores e acervos musicais no Brasil. In: SIMPÓSIO LATINOAMERICANO DE MUSICOLOGIA, 1., 1997, Curitiba. Anais [...]. Curitiba: Fundação Cultural de Curitiba, 1998.

CASTAGNA, Paulo. Avanços e perspectivas na musicologia histórica brasileira. Revista do Conservatório de Música da UFPel, Pelotas, n. 1, p. 32-57, 2008.

COELHO, João Marcos Neves. A atuação das bandas em Araranguá nas décadas de 1920 e 1930. Trabalho de Conclusão de Curso (Licenciatura em Música) - Universidade do Estado de Santa Catarina, Florianópolis, 2015. 
CONTIER, Arnaldo Daraya. Música no Brasil: História e interdisciplinaridade. Algumas Interpretações. Revista Brasileira de História, XVI Reunião da ANPUH, Rio de Janeiro, 1991.

COOK, Nicholas. Agora somos todos (etno)musicólogos. Ictus: Periódico do PPGMUS UFBA, v. 7, p. 7-32, 2006.

CÓRDOVA, Maria Cristina Neves. Terno, o canto dos reis de Sambaqui: uma etnografia de uma performance musical. Dissertação (Mestrado em Antropologia Social) Universidade Federal de Santa Catarina, Florianópolis, 1991.

CORREA, Wellinton Carlos. “Vou andar por aí: o balanço, a música e a bossa de Luiz Henrique Rosa. 2015. 247 f. Dissertação (Mestrado em História - História do Tempo Presente) - Programa de Pós-Graduação em História, Universidade do Estado de Santa Catarina, Florianópolis, 2015.

COTTA, André Guerra. O Palimpsesto de Aristarco: considerações sobre plágio, originalidade e informação na musicologia histórica brasileira. Perspectivas em ciência da informação, Universidade Federal de Minas Gerais, Belo Horizonte, v. 4, n. 2, 1999.

DEBIASI, Paulowik Pizzolatti. Banda Estrela do Oriente: "O início, o fim e o meio". 2008. 108 p. Trabalho de Conclusão de Curso (Bacharelado em Música) - Universidade do Estado de Santa Catarina, Florianópolis, 2008.

EBERHARDT. Rosenete Marlene. A memória do patrimônio musical de Joinville: uma abordagem sócio-histórica e cultural das composições de 1900 a 1950. Dissertação (Mestrado em Patrimônio Cultural e Sociedade) - Universidade da Região de Joinville, Joinville, 2012.

FERREIRA, Júlio Córdoba Pires Ferreira. Reflexões sobre o choro enquanto gênero e musicalidade e sua presença em Florianópolis/SC. Dissertação (Mestrado em Música - Musicologia/Etnomusicologia) - Universidade do Estado de Santa Catarina, Florianópolis, 2009.

FRECCIA, Gustavo Weiss. A Programação no Theatro Santa Izabel e o gosto musical em Desterro no final do Império. 2008. 64 p. Trabalho de Conclusão de Curso (Graduação em Música) -Universidade do Estado de Santa Catarina, Florianópolis, 2008.

GONÇALVES, Pedro Loch. Músicos em Desterro na segunda metade do séc. XIX. Trabalho de Conclusão de Curso (Graduação em Música) - Universidade do Estado de Santa Catarina, Florianópolis, 2012. 
GRUEZMACHER, Augusto. A banda Lyra da Aurora: aspectos da história da música em Jaraguá do Sul (SC) nas décadas de 1950 a 1970. Trabalho de Conclusão de Curso (Graduação em Música - Violoncelo) - Universidade do Estado de Santa Catarina, Florianópolis, 2017.

GUTJAHR, Simone. Atuação de músicos em associações religiosas de Desterro nos períodos colonial e imperial. Dissertação (Mestrado em Música - Musicologia/ Etnomusicologia) - Universidade do Estado de Santa Catarina, Florianópolis, 2010.

GUTJAHR, Simone. A música em Desterro (Florianópolis) nos períodos colonial e imperial. Florianópolis: [s.n.], 2018.

HOFFMANN, Kaio Domingues. Música, mito e parentesco: uma etnografia xokleng. Dissertação (Mestrado em Antropologia Social) - Universidade Federal de Santa Catarina, Florianópolis, 2011.

HOLLER, Marcos Tadeu. A música na imprensa em Desterro no séc. XIX. In:

CONGRESSO DA ANPPOM, 17., 2007, São Paulo. Anais [...]. São Paulo: Instituto de Artes da Universidade Estadual Paulista, 2007.

HOLLER, Marcos Tadeu. Fontes sobre a história da música em Desterro. DAPesquisa, Universidade do Estado de Santa Catarina, Florianópolis, v. 3, n. 1, ano 5, ago. 2007/jul. 2008, 2008.

HOOPER, Giles. The Discourse of Musicology. Londres: Ashgate, 2006.

IKEDA, Alberto. Musicologia ou Musicografia? Algumas reflexões sobre a pesquisa em Música. In: SIMPÓSIO LATINOAMERICANO DE MUSICOLOGIA, 1., 1998, Curitiba. Anais [...]. Curitiba: Fundação Cultural de Curitiba, 1998. p. 63-68.

JACQUES, Tatyana de Alencar. Comunidade Rock e bandas independentes de Florianópolis: uma etnografia sobre socialidade e concepções musicais. Dissertação (Mestrado em Antropologia Social) - Universidade Federal de Santa Catarina, Florianópolis, 2007.

LIVRAMENTO, Natália dos Santos. O violão no samba: um estudo etnográfico em Florianópolis. Dissertação (Mestrado em Musicologia/Etnomusicologia) - Universidade do Estado de Santa Catarina, Florianópolis, 2017.

LUCAS, Maria Elizabeth. Perspectivas da Pesquisa Musicológica na América Latina: o caso brasileiro. In: SIMPÓSIO LATINO-AMERICANO DE MUSICOLOGIA, 1., 1997, Curitiba. Anais [...]. Curitiba: Fundação Cultural de Curitiba, 1998. p. 69-74. 
MACEDO, Lisandra Barbosa. Ginga, Catarina! Manifestações do samba em Florianópolis na década de 1930. Dissertação (Mestrado em História) - Universidade do Estado de Santa Catarina, Florianópolis, 2011.

MARCON, Fernanda. Música de festival: uma etnografia da produção de música nativista Sapecada da Canção Nativa em Lages - SC. Dissertação (Mestrado em Antropologia Social) - Universidade Federal de Santa Catarina, Florianópolis, 2009.

MARÍN, Miguel Ángel. Contar la historia desde la periferia: Música y ciudad desde la musicologia urbana. Neuma: Revista de Música y Docencia Musical, Talca, Chile, year 7, v. 2, p. 10-30, 2014.

MEZZALIRA, José Claudio. Manoel José de Mello e Virgílio José Godinho: dois compositores de Lages - Estudo a partir de fontes do Museu Thiago de Castro. 2014. 99 p. Trabalho de Conclusão de Curso (Licenciatura em Música) - Universidade do Estado de Santa Catarina, Florianópolis, 2014.

MINOZZO, Maurício. Espaços de apresentações musicais no início do século XX em Florianópolis: uma pesquisa histórico-musicológica por meio de periódicos. 2014. 43 p. Trabalho de Conclusão de Curso (Licenciatura em Música) - Universidade do Estado de Santa Catarina, Florianópolis, 2014.

MOHR, Denise. Orquestra de Câmara São Bento do Sul, seu público e seu papel para o município. Dissertação (Mestrado em Música - Musicologia/Etnomusicologia) Universidade do Estado de Santa Catarina, Florianópolis, 2013.

MORAES, José Geraldo Vinci de. Metrópole em Sinfonia: história, cultura e música popular na São Paulo dos anos 30. São Paulo: Estação Liberdade, 2000.

MORAES, José Geraldo Vinci de. História e música: canção popular e conhecimento histórico. Revista Brasileira de História, São Paulo, v. 20, n. 39, p. 203-221, 2000b.

MOTA, Rodrigo de Souza. Rock dos anos 1980, prefixo 48: um crime perfeito? Dissertação (Mestrado em História) - Universidade Federal de Santa Catarina, Florianópolis, 2009.

NAPOLITANO, Marcos. História e música popular: um mapa de leituras e questões. Revista de História: Dossiê História e Música, São Paulo, n. 157, p. 153-171, 2007.

MACHADO NETO, Diósnio. Em vão vigiam as sentinelas: cânones e rupturas na historiografia musical brasileira sobre o período colonial. Tese (Livre-docência) Universidade de São Paulo, Ribeirão Preto, 2011. 
NEUMANN, Ricardo. A cena musical alternativa norte-nordeste catarinense entre 1990 e 2010: das ruas aos espaços virtuais. 2017. 219 f. Tese (Doutorado em História) Universidade Federal de Santa Catarina, Florianópolis, 2017.

OLIVEIRA, Márcia Ramos de. Lupcínio Rodrigues: a cidade, a música, os amigos. 1995. 248 p. Dissertação (Mestrado em História) - Universidade Federal do Rio Grande do Sul, Porto Alegre, 1995.

OLIVEIRA, Carlos Eduardo Pereira. Cabe rock nessa ilha? Formação da cena de rock em Florianópolis (1980-1989). Dissertação (Mestrado) - Universidade do Estado de Santa Catarina, Florianópolis, 2018.

ONDRUSEK, Cláudia Bonaldo. A recepção de ópera em Florianópolis. Dissertação (Mestrado em Música - Musicologia/Etnomusicologia) - Universidade do Estado de Santa Catarina, Florianópolis, 2011.

PAMPLONA, Otildes Costa Furtado. O carnaval em Desterro na segunda metade do século XIX através da atuação da imprensa e das sociedades carnavalescas. 2011. $78 \mathrm{f}$. Trabalho de Conclusão de Curso (Licenciatura em Música) - Universidade do Estado de Santa Catarina, Florianópolis, 2011.

PEREIRA, Tiago. Pela escuta de Heinz Geyer na "cidade ressoante": Música e Campanha de Nacionalização no cotidiano urbano de Blumenau - SC (1921-1945). Dissertação (Mestrado - Musicologia/Etnomusicologia) - Universidade do Estado de Santa Catarina, Florianópolis, 2014.

PIEDADE, Acácio Tadeu de Camargo. Algumas questões da pesquisa em etnomusicologia. In: FREIRE, Vanda Bellard (org.). Horizontes da pesquisa em Música. Rio de Janeiro: 7 Letras, 2010.

PIRES, Débora Costa. Atuação das sociedades musicais e bandas civis e militares em Desterro durante o Império. 2008. 48 f. Trabalho de Conclusão de Curso (Graduação em Música) - Universidade do Estado de Santa Catarina, Florianópolis, 2008.

PIRES, Débora Costa. Narciso e Eco: os periódicos como reflexos e ecos da vida musical em Desterro durante o Império. Dissertação (Mestrado em Música - Musicologia/Etnomusicologia) - Universidade do Estado de Santa Catarina, Florianópolis, 2012.

POLASTRE, Claudia Aparecida. A música na cidade de São Paulo, 1765-1822. 2008. 255 p. Tese (Doutorado em História Social) - Universidade de São Paulo, São Paulo, 2008. 
ROSA, Dyane da Silva. A canção em Desterro no século XIX. 2010. 88 f. Trabalho de Conclusão de Curso (Licenciatura em Música) - Universidade do Estado de Santa Catarina, Florianópolis, 2010.

ROSA, Hélio Teixeira da. Dicionário da música em Santa Catarina. Florianópolis: Instituto Histórico e Geográfico de Santa Catarina, 2002.

ROSSBACH, Roberto Fabiano. As sociedades de canto da região de Blumenau no início da colonização alemã (1863-1937). Dissertação (Mestrado em Música - Musicologia/ Etnomusicologia) - Universidade do Estado de Santa Catarina, Florianópolis, 2008.

ROSSBACH, Roberto Fabiano. Catalogação sistemática e descritiva de obras e fontes musicais no Brasil: o catálogo temático de Heinz Geyer (1897-1982). Tese (Doutorado em Música) - Universidade Estadual Paulista, São Paulo, 2020.

SANTHIAS, Paulo Roberto. Zzzzriguidum! Consulado: o choque do samba em Florianópolis (memórias e histórias de uma Escola de Samba encravada na cidade 1976 a 2000). Dissertação (Mestrado em História) - Universidade do Estado de Santa Catarina, Florianópolis, 2010.

SANTOLIN, Roberta Faraco. O piano em Desterro no Século XIX. 2009. 75 f. Trabalho de Conclusão de Curso (Bacharelado em Música: Piano) - Universidade do Estado de Santa Catarina, Florianópolis, 2009.

SANTOS, Scheyla Tizatto. Nas Manhãs do Sul do Mundo: música e cidade na produção do grupo Expresso Rural (1980-2012). Dissertação (Mestrado em História - História do Tempo Presente) - Programa de Pós-Graduação em História, Universidade do Estado de Santa Catarina, Florianópolis, 2013.

SCOZ, Tatiane Melissa, "Blumenau também é a cidade do rap": pensando "espaço" a partir dos rappers em Blumenau. Dissertação (Mestrado em Antropologia Social) Universidade Federal de Santa Catarina, Florianópolis, 2011.

SCHNEIDER, Alexandre da Silva. Sociedade Musical Amor à Arte: um estudo histórico sobre a atuação de uma banda em Florianópolis na Primeira República. Dissertação (Mestrado em Música - Musicologia/Etnomusicologia) - Universidade do Estado de Santa Catarina, Florianópolis, 2011.

SEZERINO, Glauber Aquiles. Brasil Caboclo: música e cotidiano na população cabocla em movimento. Dissertação (Mestrado em Sociologia) - Universidade Estadual de Campinas, Campinas, 2007. 
SILVA, Áurea Demaria. No balanço da "mais querida": música, socialização e cultura negra na Escola de Samba Embaixada Copa Lord - Florianópolis (SC). Dissertação (Mestrado em Música) - Universidade Estadual Paulista Júlio de Mesquita Filho, São Paulo, 2006.

SILVA, Rodrigo Moreira da. "Ratoeira não me prende, que eu não tenho quem me solta": música de tradição oral e identidade cultural no litoral de Santa Catarina. Dissertação (Mestrado em Música - Musicologia/Etnomusicologia) - Universidade do Estado de Santa Catarina, Florianópolis, 2009.

SILVA, Marcelo da. Ué gaúcho, em Floripa tem samba? Uma antropologia do samba e do choro na Grande Florianópolis ontem e hoje. Dissertação (Mestrado em Antropologia Social) - Universidade Federal de Santa Catarina, Florianópolis, 2012.

SOUZA, Ângela Maria de. O movimento do rap em Florianópolis: a ilha da magia só da ponte pra lá. Dissertação (Mestrado em Antropologia Social) - Universidade Federal de Santa Catarina, Florianópolis, 1998.

SOUZA, Ângela Maria de. A caminhada é longa... E o chão tá liso: o movimento hip hop em Florianópolis e Lisboa Tese (Doutorado em Antropologia Social) - Universidade Federal de Santa Catarina, Florianópolis, 2009.

SOUZA, Marcel Oliveira de. A voz do progresso: música e modernização nas ondas da rádio clube de Lages - SC. Dissertação (Mestrado em Música - Musicologia/ Etnomusicologia) - Universidade do Estado de Santa Catarina, Florianópolis, 2012.

SOUZA, Marco Antonio Ferreira de. Entre a cantoria e a nossa barulheira: Florianópolis nas canções do Grupo Engenho e da banda Dazaranha (1980-2004). 2014. 148 f. Dissertação (Mestrado em História) - Programa de Pós-graduação em História, Universidade do Estado de Santa Catarina, Florianópolis, 2014.

SPESSATTO, Luiz Fernando. Maestro Alfredo Sigwalt (1915-1994) e a sociedade de cultura artística de Joaçaba e Herval D'Oeste (SCAJHO): contribuições para a história cultural de Joaçaba - SC nas décadas de 1950 a 1970. Dissertação (Mestrado em Musicologia/Etnomusicologia) - Universidade do Estado de Santa Catarina, Florianópolis, 2017.

SPINDOLA, Elaine Miguel. Santa Catarina nos versos e na safona: análise de canções de Pedro Raymundo em uma perspectiva nativista. Dissertação (Mestrado em Ciências da Linguagem) - Universidade do Sul de Santa Catarina, Tubarão, 2014. 
SPROGIS, Voldis. Voluntários da música: um estudo histórico sobre a atuação da Banda de Música do Corpo de Bombeiros Voluntários e se papel em Joinville de 1967 a 1974. Dissertação (Mestrado em Musicologia/Etnomusicologia) - Universidade do Estado de Santa Catarina, Florianópolis, 2015.

TÉO, Marcelo Robson. A vitrola nostálgica: música e constituição cultural em Florianópolis (1930-1949). Dissertação (Mestrado em História) - Universidade Federal do Rio Grande do Sul, Porto Alegre, 2005.

TÉO, Marcelo Robson. A vitrola nostálgica: música e constituição cultural (Florianópolis, décadas de 1930 e 1940). Florianópolis: Letras Contemporâneas, 2007.

THEISS, Sérgio Luís. Uma cidade que (en)canta: aspectos e tensões na cultura musical de Blumenau - 1937-1945. Trabalho de Conclusão de Curso (Bacharelado em História) - Universidade Regional de Blumenau, Blumenau, 2009.

ULLER, Andrei Jan Hoffmann. A música ítalo-trentina nos municípios de Nova Trento, Rio dos Cedros e Rodeio: algumas considerações sobre a história e a atualidade desta manifestação. 2008. 80 f. Trabalho de Conclusão de Curso (Licenciatura em Música) Universidade do Estado de Santa Catarina, Florianópolis, 2008.

VIEIRA, Natacha Kamila. Sebastião Bousfield e o movimento musical em Florianópolis nas décadas de 1930 e 1940. Trabalho de Conclusão de Curso (Graduação em Música - Violino e Viola) - Universidade do Estado de Santa Catarina, Florianópolis, 2013.

WERLING, Camila. A música como representação dos movimentos germânicos e não-germânicos em Blumenau nas décadas de 1970 e 1980. Dissertação (Mestrado em Musicologia/Etnomusicologia) - Universidade do Estado de Santa Catarina, Florianópolis, 2016. 